\title{
La narrativa de Adriana González Mateos. Evasión, erotismo y violencia
}

\section{The narrative of Adriana González Mateos. Evasion, eroticism and violence}

\author{
Marisol Nava Hernández \\ Universidad Autónoma de Tlaxcala, México
}

Resumen: Adriana González Mateos (1961) es una de las escritoras mexicanas más relevantes de las últimas décadas. Su importancia radica en la calidad estética evidenciada en Cuentos para ciclistas y jinetes y El lenguaje de las orquideas. Temáticamente, ambas obras abordan la evasión de la cotidianeidad mediante el erotismo y la violencia, lo cual analizaremos en el presente trabajo. Particularmente, nos centraremos en sus personajes femeninos: las adolescentes (con sus respectivas iniciaciones eróticas) y las mujeres adultas (con sus problemáticas interpersonales), marcadas por la ausencia o libre demostración del erotismo. Dichas tematizaciones se enriquecen con el hábil recurso de las historias alternas o superpuestas, además del uso de diversos símbolos.

Palabras clave: Adriana González Mateos, narrativa, evasión, erotismo, violencia.

Abstract: Adriana González Mateos (1961) is one of the most important Mexican writers in the last decades. Her relevance resides in her aesthetic value performed in Cuentos para ciclistas y jinetes y El lenguaje de las orquideas (Tales for cyclists and riders, and The language of orchids). Thematically speaking, both works show the evasion of everyday life through eroticism and violence, which will be analyzed in this article. Particularly, we will be focused on her female characters: the teenagers (in their respective erotic initiation) and adult women (with their interpersonal problems), which are marked by the absence or free demon- 
stration of eroticism. These issues are enriched with the skillful ability of the writer to create alternative or embedded stories, as well as the use of different symbols.

Keywords: Adriana González Mateos, Narrative, Evasion, Eroticism, Violence.

\section{Preámbulo}

$\mathrm{D}$ urante la década de los 60, nacen destacados narradores mexicanos como Ana García Bergua (1960), Mario Bellatin (1960), David Toscana (1961), Héctor de Mauleón (1963), Javier García-Galiano (1963), Mario González Suárez (1964), Cristina Rivera Garza (1964), Eduardo Antonio Parra (1965), Pedro Ángel Palou (1966), Mauricio Montiel Figueiras (1968), Jorge Volpi (1968), Ignacio Padilla (1968-2016) y, por supuesto, nuestra narradora y objeto de este trabajo, Adriana González Mateos (1961).

Originaria de la Ciudad de México, Adriana González Mateos estudió Letras Modernas en el ITESM, Literatura comparada en la UNAM y el doctorado en el Colegio de México. Esta firme formación académica le ha permitido ser traductora de poesía estadounidense y guionista de radio y televisión; además, ha colaborado en Casa del Tiempo, La Jornada Semanal y Sábado. Asimismo, ha sido becaria del FONCA (1992) y de la Fulbright (1995). También, entre otros reconocimientos, ha sido merecedora del Premio de Traducción de poesía (1996), cuyo trabajo versó sobre Williams Carlos Williams, realizado en colaboración con Myriam Moscona.

Adriana González Mateos ha escrito escasas obras. Comienza su trayectoria literaria en 1995 con Cuentos para ciclistas y jinetes, hasta el momento su único libro de cuentos, reconocido ese mismo año con el Premio Nacional de Literatura Gilberto Owen y el cual ostenta urdimbres complejas con dos o más historias entrelazadas y una amalgama de voces narrativas, predominando los personajes 
femeninos. Le sucede el libro de ensayos, Borges y Escher. Un doble recorrido por el laberinto, ganador del Premio Nacional de Ensayo Literario José Revueltas (1996) que fue publicado en 1998. Pasarán varios ańos para la publicación de su siguiente obra ficticia y primera novela, El lenguaje de las orquideas del 2007, cuya protagonista, mediante analepsis, refiere su transgresor incesto, lo que da como resultado una narración íntima, confesional y catártica desde el enfoque de la voz narrativa. ${ }^{1}$

Cuentos para ciclistas y jinetes está conformado por un prólogo y diez cuentos, de los cuales excluimos para este trabajo "Pruebas de imprenta" e "Invasión", pues su temática principal es la creación literaria expuesta mediante recursos metaficcionales. Por tanto, "Gatúvela", "Sueño con enredadera", "Solitarios", "Toros", "Catástrofes remotas", "Cacería nocturna”, "Lejos" y "Cuento Kitsch", además de El lenguaje de las orquideas, configuran nuestro objeto de estudio.

El criterio para elegir este corpus radica en que, a pesar de los doce años que separan la publicación del cuentario y de la novela, sus vínculos son significativos. En primer lugar, en ambas obras predominan dos tipos de personajes: las adolescentes y las mujeres adultas. En segundo lugar, sus temáticas relevantes son la evasión, el erotismo y la violencia. Finalmente, El lenguaje de las orquídeas recupera íntegramente el cuento "Toros" de Cuentos para ciclistas y jinetes inserto como el capítulo $\mathrm{V}$ en la novela, estableciéndose un diálogo intratextual. El análisis de estos nexos entre ambas obras conforma nuestro objetivo.

Partamos de una situación de los personajes femeninos: el anhelo de alejarse de lo rutinario, lo cual se observa desde el prólogo de Cuentos para ciclistas y jinetes titulado "Naturaleza muerta con bicicleta":

${ }^{1}$ Después de estas obras, la autora ha publicado la novela Otra máscara de Esperanza (2015) y el libro de crónicas And then...Andenes. Crónicas DF NY(2015). 
[...] desde el periódico saltaban noticias de derrumbes y encabezados: «Textura del espacio-tiempo», «Últimas bondades del índice bursátil». La ventana dejaba ver el manubrio de la bicicleta como un llamado a la lejanía, a la velocidad, a otras partes más allá de la cocina donde hasta la escalera era previsible y el brillo de los sartenes impedía ver nada más [...] Rodemos lejos de las cocinas, las ondas de espaguetti, la plenitud de las vajillas y los principios anotados en libros de recetas, lejos de la proximidad de los botes de basura, del sonido del teléfono, de todo vuelo de merengue. Afuera están las bicicletas (González Mateos, 1995: 9-10).

Cotidianidad representada por un espacio concreto: la cocina en particular y la casa en general, lugar tradicionalmente femenino y substancial porque los personajes protagónicos de Cuentos para ciclistas $y$ jinetes son mujeres que, en mayor o menor medida, se relacionan con ese espacio, símbolo de su deslucida realidad. Al respecto, en una entrevista a José Antonio Lugo, la autora indica:

Los personajes de este libro viven una realidad opresiva, frustrante o que les da miedo y lo que quieren es escapar; de allí la imagen de los jinetes y la bicicleta [...] bicicletas y caballo tiene algo en común, que para subirse a ellos hay que abrir las piernas. Los personajes de este libro ven en el sexo la posibilidad de escapar o investigar otros territorios (1995: 35).

El ámbito femenino, identificado con el topos doméstico, y su posterior evasión mediante el símbolo del caballo y el jinete resurgen en El lenguaje de las orquideas: "Juntas amábamos a esas heroínas capaces de montar a caballo para enfrentar los peligros, envenenar a un carcelero, seducir a un héroe inconveniente, burlarse de las estúpidas que se quedan en casa obedeciendo y se pierden la mejor parte del libro" (2007: 63). Cuentos para ciclistas y jinetes y El lenguaje de las orquideas parten de la cerrazón del espacio domésti- 
co y del deseo de evadir las impuestas rutinas a través del erotismo y de la violencia.

Para analizar este binomio temático, consideramos básicamente la propuesta de George Bataille, pues la díada erotismo-violencia es ampliamente analizada por el estudioso francés, aunque no descartamos las propuestas de otros teóricos como Giuseppe Amara, René Girard o Santiago Genovés. Los planteamientos de Bataille parten del deslinde entre erotismo y sexualidad:

La actividad sexual reproductiva la tienen en común los animales sexuados y los hombres, pero al parecer sólo los hombres han hecho de su actividad sexual una actividad erótica, donde la diferencia que separa al erotismo de la actividad sexual simple es una búsqueda psicológica independiente del fin natural dado en la reproducción y del cuidado que dar a los hijos (2008: 15).

Desde este enfoque, el erotismo provee de continuidad a los seres discontinuos que somos y, para ello, la prohibición y su subsiguiente transgresión son ineludibles. Parte de esta contravención se halla en la violencia ejercida en el acto erótico: "El terreno del erotismo es esencialmente el terreno de la violencia, de la violación" (21); en este sentido, lo más violento para el hombre es la muerte al enfrentarlo con el imposible sueño de pervivencia de su ser discontinuo. El erotismo se enlaza con la violencia, a esto se debe su fuerte tono transgresor.

Por su parte, René Girard estudia el binomio violencia-sexualidad, cuyo trasfondo es similar a lo planteado por Bataille; al respecto comenta:

Con mucha frecuencia la sexualidad tiene que ver con la violencia, tanto en sus manifestaciones inmediatas -rapto, violación, desfloración, sadismo, etc.- como en sus consecuencias más lejanas [...] el deslizamiento de la violencia a la sexualidad, y de la sexualidad a la violencia, se efectúa con gran facilidad, en ambos 
sentidos, incluso en las personas más «normales» y sin que sea necesario invocar la menor «perversión» (1998: 42).

La sexualidad indicada por Girard precisa su naturaleza y relevancia en el erotismo estudiado por Bataille, en donde la violencia irrumpe, signándolo todo.

Con base en estos planteamientos, las protagonistas de Cuentos para ciclistas y jinetes y de El lenguaje de las orquideas recurren al erotismo y su inherente violencia para desligarse de su entumecida realidad. En concreto, observamos dos etapas, bien diferenciadas, en las protagonistas: las adolescentes con sus respectivas iniciaciones eróticas y las mujeres adultas con sus problemáticas interpersonales, marcadas por la ausencia o libre muestra del erotismo.

\section{Las adolescentes y sus iniciaciones}

Cuentos para ciclistas y jinetes expone cuatro cuentos ("Gatúvela", "Sueño con enredadera", "Solitarios" y "Toros") en donde predominan las protagonistas púberes, cuya apremiante rutina emerge por los cambios físicos gestados en ellas y por sus tediosas relaciones escolares y familiares. Sin embargo, esta cotidianidad se altera y soslaya por su singular proceso de iniciación erótica, en donde la violencia irrumpe a veces soterrada y en ocasiones ostensiblemente.

En "Gatúvela”, la vida de Berta transcurre entre las preocupaciones sobre su desarrollo físico, enfatizado en el incipiente crecimiento de sus senos y en las dudas sobre su primera menstruación; a ello se suma la eterna curiosidad por conocer el cuerpo, también en plena evolución, del otro, del varón:

[...] Berta lamió el polvo de chile y le exprimió más limón y dijo no creo no puede ser tan grande y Tere confesó que eso último lo había inventado pero tiene que ser por el estilo, sí, no me explico 
pero no puede ser tan largo te juro que así estaba pintado en la pared hay que espiarlos pero de todos modos es distinto, no ves que se les para yo no entiendo cómo yo tampoco (1995: 37-38).

Otro factor determinante en la vida de Berta es su vida escolar, en la cual imperan las clases y los enfrentamientos entre varones y chicas para identificar al grupo más poderoso. Igualmente se encuentra su vida familiar, destacando el mandato de sus padres para sólo ver caricaturas y, por tanto, la prohibición de los programas nocturnos, exigiéndole dormir temprano: “y todo se convertiría en un programa de otro canal de esos que obligan a cambiar, a buscar anuncios o caricaturas y jamás le sirven a Berta para nada cuando mamá y papá la mandan a dormir y se quedan viendo la televisión" (36).

Estas inercias se interrumpen con la iniciación erótica de Berta, en donde la imaginación desempeña un rol fundamental, pues la protagonista se imagina siendo otra, Gatúvela, y crea imaginariamente al "otro", Batman. Por ello, la violencia vinculada al erotismo se concreta gracias al ambiente policiaco y criminal, protocolo de la serie televisiva de "Batman", y escenario de la fantasía erótica de Berta, pues imagina que Batman la acosa en su papel de Gatúvela:

Él sabe que acaba de alcanzarla está atrapada entre la fachada y los vientos que aúllan a lo largo de los edificios sólo necesita silenciar sus protestas apretarla contra el muro obligarla a doblar la cabeza hacia atrás y hundirse en su boca para conocer su identidad y olvidarse de las máscaras las armas los batiinstrumentos trenzarse en una lucha donde ya nadie sabe cuáles uñas se clavan en qué carne cuáles piernas cuál boca se abre para gritar o atrapar la otra que maúlla o insulta o procura articular alguna contraseña (38).

La iniciación de Berta es paradójica, pues sus padres sólo le autorizan ver caricaturas $y$, por el contrario, le impiden ver pro- 
gramas nocturnos e incluso la mandan a dormir con el objetivo de salvaguardarla del erotismo y de la violencia contenidos en estos programas; sin embargo, esta restricción le posibilita acceder al conocimiento erótico en su propia cama y con un personaje de los comics; es decir, Berta transgrede con lo permitido, infringiendo los preceptos familiares y desencadenando una placentera fantasía erótica y orgásmica:

[...] como él cuando siente las zarpas en la carne y a su vez la muerde y para los tres es insoportable como si doliera y tratan de envolverse en esa sensación que se fuga siempre más adentro pero caen en una confusión de capas y ventanas y estrellas cada vez más altas y se hacen confesiones pero caen y todo está a punto de borrarse y zozobrar mientras caen caen en la humedad de la noche llena de precipicios que Berta tiene adentro (39).

La iniciación de Berta, desarrollada en su imaginación mediante esta atmósfera erótico-violenta, resulta satisfactoria al contrapuntear las opacidades de su contexto fisiológico, escolar y familiar.

Por su parte, "Sueño con enredadera" presenta a Celia, otra púber cuya vida acontece entre el desconocimiento, preocupación y curiosidad por su desarrollo físico:

¿Es cierto que se dan cuenta si te está bajando? Dicen que te pones diferente en esos días, no puedes mojarte pero es un olor fuerte, si te aprietan la mano te descubren, salen granos, a la hermana de Alicia le dan cólicos [...] No entiende, las piernas se te están poniendo gordas, odias que te miren. Todos se dan cuenta. Por más que te pongas pantalones anchos, camisetas largas, por más que cruces los brazos y quieras jorobarte (43).

Similar al cuento anterior, las actitudes de los varones son cruciales por lo incomprensibles e inquietantes; por ejemplo, pintar mujeres desnudas. A esto se aúna el interés de las púberes por el 
cuerpo masculino en pleno crecimiento: "ellos también están cambiando, pintan pollos, swásticas, cosas que gotean, calaveras. Pero no les baja, claro no les baja igual pero quién sabe" (44). El contexto escolar también interviene en la monótona vida de Celia pero, a diferencia de Berta en "Gatúvela", éste se muestra incompatible con sus intereses: "Tienes sed, cara de fastidio, odias la escuela, odiamos cada signo de gis, cada tarea" (44).

La suma de estas circunstancias suscita la iniciación erótica de la protagonista, la cual se verifica mediante un sueño repleto de símbolos sexuales y eróticos que devienen fracaso al ser incomprensibles para la joven; esta situación se anticipa desde el inicio de su experiencia onírica: "Un sueño lleno de esas ramas, se enroscaban, se iba poniendo más oscuro, cubrían una muralla, tratabas de subirte, se rompían y caías al suelo, te dejaban manchas en las manos" (43), donde el léxico predominante denota el malogro del proceso, el intento mas no el triunfo. El sueño continúa:

Así fue la pesadilla. Te salían plantas en las manos, pelos, te los arrancabas, se formaban costras, no sé nidos de arañas, hormigas, pelos en las piernas, hojas enfrente de los ojos, animales, cosas llenas de antenas y de patas. No podías correr, no sé por qué quieres contarlo [...] Sergio tenía en las manos algo negro, una cosa larga, se retorcía, una víbora de agua. Grande, forcejeaba entre sus dedos. Fue muy rápido, la puso en el suelo, muy cerca del árbol, no te vio porque la estaba deteniendo, son muy fuertes y creíste que podía escaparse pero la pisaba con el tenis sin matarla, sólo para que no se fuera [...] levantaba la cabeza con la boca abierta, los colmillos, lanzaba la lengua negra, dividida como dos flechas puntiagudas [...] Azotaba la cola, casi cortada en dos pero quería morderme, escupir, tenías que arriesgarte a pasar cerca de ti que te cayera sangre o baba porque se retorcía, esas escamas, abajo tiene escamas amarillas [...] Pero silbaba. Adentro de la boca tenía blanco, membranas, una cosa negra, babas (45-46). 
La protagonista describe el sueño mediante referentes conocidos para ella: arańas, hormigas y víbora, animales usualmente considerados nocivos. La víbora destaca como símbolo sexual ambiguo: masculino por su forma fálica y femenino porque, semejante al vientre, todo lo devora (Becker, 1999: 291); no obstante, en el cuento adquiere una mayor connotación fálica por su forma larga y retorcida; a ello se suma su lengua a modo de flechas, las cuales poseen un sentido similar (Cirlot, 2007: 211). Estos símbolos masculinos, evidentemente fálicos, se complementan con el anhelo de la víbora por escupir baba, cuyo aspecto remite al semen.

Como se percibe, la violencia signa todo el sueño: Celia cae de la muralla, ve su cuerpo atiborrado de pelos, unos nińos atropellan a la víbora con su bicicleta dejándola malherida, aunque con la capacidad para morder y escupir a Celia, quien se siente acorralada. Por las imágenes violentas contenidas en el sueńo $\mathrm{y}$, a diferencia de "Gatúvela", la iniciación erótica de Celia se frustra, pues esa experiencia onírica no resulta placentera, por el contrario, obstaculiza su conocimiento y le provoca un mayor temor, desconfianza e incertidumbre manifestada en su relación con los varones: "Es más, uno de ellos pidió que te invitara, ha de ser David, David te mira. No es para tanto, Celia, no les tengas miedo" (1995: 48). El cuento concluye con los temores de Celia, pues su sueño eróticoviolento no se tradujo en una experiencia plácida, por el contrario, la deja en una búsqueda inconclusa.

"Solitarios" es un cuento donde, a decir de Eduardo García Aguilar, "se expresa con mayor brillantez el talento de la autora, para conducirnos a un contrapunteo gótico con sus propias leyes de espadachines, caballerangos, barajas, cortinajes, escaleras que se enroscan, trampas, diamantes, peldaños, guardias acechantes, monjas, hábitos solitarios" (1996: 15). En efecto, el cuento presenta dos historias a modo de cajas chinas, cuyos narradores son intradiegéticos. 
La narradora de la primera historia es una adolescente, cuya vida transcurre entre afrontar a su "mamá cada día más segura sobre las expresiones de mi cara y sus matices, más horas en la escuela, uniforme con falda de tablones, inminente fiesta de quince años" (González Mateos, 1995: 83); esta monótona inercia adquiere dinamismo gracias a una baraja con la cual juega solitario y, además, le permite imaginar historias; así, baraja e imaginación facultan a la joven para "fugarme por sus eternas escaleras, un país de reinas encarceladas con sus flores en la mano, emisarios, espadachines, caballeros de perfil como si acabaran de oír un ruido entre los cortinajes" (68).

La segunda historia se relaciona con esta ensonación, y tiene dos narradores. Por un lado, una joven huérfana que, mediante el género epistolar, aborda su vínculo con un joven desconocido, del cual anhela se haya "decidido a todo con tal de rescatarme y una de estas noches me despertará su voz al otro lado de mi puerta; lo veré disfrazado de criado, de caballerango" (66). Ese rescate será del encierro en el que la mantiene confinada su tío y tutor, un duque rígido y ambicioso, quien anhela seguir salvaguardando la herencia de la chica y en cuya relación se enfatiza la violencia ejercida por este hombre: "la última vez pasé dos horas oyendo regaños, amenazas sobre un nuevo capellán capaz de meterme en cintura [...] no paró de gritar. Ahora quiere que me corte el pelo y lleve una cofia" (69). Por otro lado, el narrador es un joven, el cual ha incursionado en el castillo donde se encuentra recluida la doncella con el fin de rescatarla: "Ojalá me hubiera ido a la corte, ojalá siguiera cazando en los bosques de mi padre, perfeccionando mi esgrima y oyendo rumores sobre intrigas en vez de haberme sumado a quienes se empeñaron en rescatarla y dejaron sus huesos en estas covachas" (64); aunque pareciera la joven narradora se dirige a este personaje, hacia el final se descubre que es otro chico 
distinto al de su ensonación; no obstante, la conclusión de esta historia presupone el encuentro de la pareja y su posterior huida.

Lo relevante de ambas historias es su conexión, pues se imbrican configurando una imagen especular, en tanto la narradora de la primera historia toma como pretexto la segunda creada en su imaginación mediante la baraja, para recordar las vivencias con su primo, una historia de juegos, complicidades y despertar erótico: "cerré los ojos y sentí qué rara piel, qué raro tocar tus labios, descubrir qué se siente aunque no sientas claramente nada" (81). Así, la inminente llegada del primo, tras años de separación y distancia, motiva la fantasía de la joven, quien hacia el final declara: "Hay otra carta, nadie sabe que la tengo, no está prevista por las reglas, pero cuando regreses nos toca nuestro turno. Y nadie sospecha cómo vamos a tirarla" (84), en dicha relación sobreviene el amor, el deseo y un muy sutil erotismo, pues sólo se anticipa tenuemente tal iniciación.

En “Toros”, semejante a los anteriores cuentos, se destaca la rutinaria vida de la protagonista; la diferencia radica en el contacto indiscutible con el erotismo, pues su iniciación implica un brutal enfrentamiento con el otro. Mediante un narrador en segunda persona, accedemos a esta inquietante historia: en la casa de la chiquilla se lleva a cabo una reunión familiar; en un momento determinado la adolescente sube a la planta alta y entra a un cuarto atraída por el ruido del televisor; ahí encuentra a un hombre, presuntamente conocido para la chica, quien la obliga a hacerle una felación.

Esta protagonista, acorde a las anteriores, busca alejarse de lo acostumbrado: la reunión familiar, los juegos con los otros infantes y el lavar los trastos, situándose en una zona intermedia donde es una niña juguetona, pero también una púber a quien le gusta "escuchar las conversaciones de los grandes, muy callada" (49), es decir, se halla en un punto equidistante entre el mundo infan- 
til y el adulto. Hay en la joven un afán conspicuo por conocer el ámbito de los adultos al querer "averiguar inconscientemente" (Genovés, 1993: 145), justificación de su acceso al cuarto de la planta alta donde se escucha la televisión. Su curiosidad e interés se alude en el epígrafe como elemento paratextual: "Alza unas tijeras cerradas y pregunta: —¿Qué forma evocan estas líneas?” (González Mateos, 1995: 49), las tijeras son símbolo del falo (Becker, 1999: 315), motivo retomado por el desconocido hombre cuando indica el gusto de la niña por jugar con ellas.

El ingreso de la protagonista al cosmos de los mayores implica una iniciación erótico-violenta, de la cual desconoce todo: "Aún no conoces tretas de mujeres, no puedes encontrar las palabras ni los gestos ni las mañas" (González Mateos, 1995: 50). La iniciación se origina cuando, en su averiguar inconsciente, entra al cuarto donde sobreviene una escena violenta, pues el hombre domina a la chica y la somete a su voluntad:

Cállate, ya bastante torpe eres, sientes los dedos en la nuca, te estás portando mal, tu mamá puede enterarse, apartas la cabeza [...] la mano empuja para que busques en la ropa. Los dientes del cierre raspan tu mejilla, si alguien abajo se da cuenta pero tiene que abrir la boca y eso no hace ruido aunque trates de zafarte [...] quieres apartar la cabeza y ves la hebilla del cinturón, la vena hinchada, de qué te va a servir cerrar los ojos [...] Vas a tragar pese al reflejo de ahogo en tu garganta, a mamar como un becerro (50-51).

El hombre se impone utilizando el cuerpo de la chica sin el menor reparo e ignorando su decisión, deseos y necesidades (Amara, 1998: 122). La violencia se acentúa pues agrede a un sujeto doblemente vulnerable: una nińa-mujer (296). Esta violenta relación adquiere mayor gravedad por el contexto donde se desenvuelve, es decir, una reunión de primos, abuela, padres y otras personas no especificadas (pero muy próximas), lo cual indica una típica reu- 
nión familiar con comida, cigarros, café, música y conversaciones; por tanto, el hombre forma parte de esta familia, incluso no está con los demás en la planta baja, sino arriba y viendo televisión, o sea, en un lugar y en unas circunstancias reservadas, generalmente, para los dueños de la casa o miembros muy allegados a éstos. Dicha familiaridad irrumpe al final cuando el hombre le asegura a la niña: "no te asustes, te defiendo si dicen que eres una niña rara, si se burlan de que eres silenciosa. No te asustes: si alguien piensa pensará sólo que estamos aquí, tú y yo viendo los toros" (González Mateos, 1995: 51). La iniciación erótica de la chica es ineludiblemente violenta por la sugerencia del incesto y por la imposición del personaje masculino.

La destreza narrativa en "Toros" se aprecia en la integración de tres historias: la iniciación erótica realizada en la planta alta, la reunión familiar en la planta baja y la corrida de toros exhibida en la televisión. La primera y la última destacan por su paralelismo simbólico: la existencia de una víctima (el toro en la corrida y la niña en la iniciación) y el verdugo masculino (simbolizado por el torero en la fiesta taurina y por el hombre en el proceso iniciático). Debido a esta intercalación de historias, la violencia de la iniciación se incrementa por la ejercida por su historia televisiva, es decir, el toro en el espectáculo taurino:

Mata recibiendo, la bestia retrocede con el fierro en los pulmones, obligándola a respirar su propia sangre, a perder el rumbo pero sientes los dedos en la nuca [...] Sus vísceras escupen el estoque, se rasga la piel rota. El mugido no llega a ningún lado, tropieza, la arena se incrusta en sus narices y por fin reconoce la fetidez de sangre seca, pisoteada en este círculo que aúlla (51).

Varios símbolos violentos irrumpen en "Toros”. La sangre es uno de ellos (Bataille, 2008: 58). Igual importancia adquiere el toro, personificación de la fuerza viril. Finalmente, la protagonista 
menciona al zopilote, representación de la muerte al ser un animal de rapiña en espera de su presa para destruirla (Becker, 1999: 57); significativamente, la niña asemeja al hombre con este animal, quien ciertamente la convertirá en su presa.

El lenguaje de las orquideas también narra un incesto entre una adolescente y su tío; la transgresora historia convierte a la novela en "un relato sofocante y contundente, que en ninguna de sus páginas aspira a la ejemplaridad ni a deducir un escarmiento de un episodio que sólo en su dimensión de literatura adquiere su verdadera gravedad" (Domínguez Michael, 2007). De este modo, la narradora, en un presente narrativo como adulta, se evoca a sí misma y recapitula las situaciones definitorias de su adolescencia: clases, familia, religión, aburrimiento; lo único divertido era compartir y leer historias con su abuela. En ese contexto, la protagonista recuerda la complicidad, al principio sutil, surgida con su tío y la cual, lentamente, fue adquiriendo tintes infractores vinculados con su iniciación erótica: "El pijama es de una tela muy delgada, un algodón que se empapa inmediatamente mientras mi tío traza con los dedos las formas todavía esquemáticas y simplificadas de mi sexo" (González Mateos, 1995: 22). Esta experiencia, similar a sus lecturas, le permite a la chica conocer otros mundos, otras experiencias placenteras: "el camino del bien. Cuando lo abandoné disfruté una sensación de aventura y audacia, un cierto terror a lo desconocido acompañado del alborozo de conquistarlo, la euforia del desafío, curiosidad" (23).

Por supuesto, en este despertar erótico juega un papel imprescindible la transgresión: "El incesto es una sombra que cobija a sus agraciados con esa certeza: nadie es como yo. Al practicarlo salí de los límites, de todos los remedos de orden, hice lo radicalmente prohibido" (24). Como lo indica George Bataille, el erotismo implica la transgresión de lo ilícito (2008: 43) y esta historia lo patentiza con el tabú del incesto, el cual es agravado por la violencia, 
pues el tío, en su papel dominante, daña a la chica: "necesito volver sobre ese detalle: por qué necesitaba ańadir la crueldad. Una frase, el montaje de una situación, un movimiento podían contener una crueldad más basada en indicios que en la violencia abierta" (González Mateos, 2007: 42). Interdicto, transgresión y violencia confluyen en esta iniciación erótica.

Como se observa, El lenguaje de las orquideas explora el esquema analizado en los cuentos anteriores: adolescentes aburridas, despertar erótico y violencia. Sin embargo, establece un vínculo sólido e irrefutable con "Toros", pues ambas historias abordan un incesto e incluso la autora recurre directamente al cuento, como un mecanismo intratextual, para enfatizar ello. Respecto a la intratextualidad como recurso literario, José Enrique Martínez Fernández declara:

Hablo de intratextualidad cuando el proceso intertextual opera sobre textos del mismo autor. El autor es libre de aludir en un texto a textos suyos pasados y aun a los previsibles, de autocitarse, de reescribir este o aquel texto. La "obra” es, por así decir, una continuidad de textos; retomar lo que se ha dicho ya es una manera de dar coherencia al conjunto textual, a nivel formal y semántico; es una forma de lograr que el texto sea un verdadero "tejido" (2001: 151-152).

Como lo indicamos al inicio, Adriana González Mateos recupera "Toros" de Cuentos para ciclistas y jinetes y lo inserta en El lenguaje de las orquideas como el capítulo V. El recurso intratextual es evidente, pues el cuento aparece con mínimos cambios, los cuales son básicamente de puntuación. Por supuesto, la sugerente historia del cuento se explicita en la novela, pues sus silencios se aclaran al contextualizarse en la trama novelística: el hombre que somete a la niña es su tío; la narradora ha crecido y refiere esta historia, a 
manera de conjuro, para enfrentar a su madre, a su tía e incluso a su tío, hoy envejecido.

\section{Las adultas y sus problemáticas}

"Catástrofes remotas", "Cacería nocturna", "Lejos" y "Cuento Kitsch" de Cuentos para ciclistas y jinetes, así como El lenguaje de las orquideas presentan personajes femeninos adultos con problemáticas personales y familiares, aunque con un esquema similar de evasión de su rutina y distinguidas por la ausencia o libre demostración del erotismo y la violencia.

En "Catástrofes remotas", Cecilia visita a sus padres, quienes ostentan una relación de hartazgo, debido a la tortuosa convivencia diaria, agravada con la enfermedad del padre y el cansancio subsecuente de la madre. En este cuento, por encima de los otros, la acre cotidianidad es más abrumadora y frustrante para la protagonista: "Le gustaría hacer lo mismo, dormir la siesta como papá y como la perra en vez de haber lavado los platos igual que todos los domingos y disponerse a tomar una taza de café, a escuchar lo que mamá ha hecho toda la semana" (1995: 25); fastidio perenne, pues Cecilia, a sus treinta y seis años, vive sola y trabaja en una oficina, sin ninguna diversión o escape.

La consuetudinaria frustración de Cecilia se intensifica cuando su madre le evoca a Blanca, su amiga de infancia y poseedora de los grandes vacíos de Cecilia: inteligencia, profesión, matrimonio, divorcio, hija. Incluso, su madre siempre la compara con Blanca, convirtiendo el supuesto amor maternal benéfico en algo malsano, pues acentúa la frustración e impotencia de su hija, pese a la actual y problemática vida de Blanca (engañada por el marido, asediada por su jefe y con un trabajo incierto para mantener a su hija). Por todo ello, Cecilia vive en ese tiempo lineal y rutinario, el tiempo 
profano y ajeno al erotismo según George Bataille (2008: 46), el cual la ha sumergido en la soledad, petrificándola.

Similar a "Toros", en "Catástrofes remotas" la habilidad narrativa de Adriana González Mateos se refleja en la superposición de tres historias: la de Cecilia, la de Blanca y la de Sohad Belhadj. Esta última es una nińa árabe a quien le cortan el clítoris para prevenir su infidelidad y cuya historia se presenta en un periódico leído por Cecilia:

Pocas palabras, frases cortas, bastaba describir cómo los parientes seguían la fiesta en el cuarto de junto; algunas risas llegaban al plomero mientras el peluquero jalaba a Sohad hacia atrás y permitía que el otro le abriera las piernas en una $\mathrm{V}$ muy amplia. A continuación se inclinaba entre las piernas de la niña y le cortaba el clítoris (el reportero no resistía la tentación) utilizando las tijeras de la peluquería. Sohad empezaba a gritar antes de que la enderezaran y empezaran a vendarla [...] así creen evitar la infidelidad de las mujeres, no se usó anestesia (1995: 31-32).

Historia violenta y crucial para la protagonista, pues las imágenes agresivas compensan el aburrimiento de la vida cotidiana, ejerciendo una pasiva violencia; este proceso funciona por el efecto catártico de la imagen violenta que libera las tendencias destructivas y la violencia reprimida a través de la identificación con los sufrimientos de la víctima o con los excesos del victimario (Amara, 1998: 337). De este modo, Cecilia suple sus tendencias destructivas provocadas por su soledad y frustración, a través de la imagen violenta de Sohad, actuando con una violencia pasiva, la cual se distingue en sus severos comentarios respecto a la niña: "Cecilia se la había imaginado perfecto al leer por primera vez la nota, la escuincla de nueve años es el centro de la fiesta y está a punto de recitar o bailar o hacer cualquier monería para regocijo de los tíos, choferes o vendedoras del mercado" (29), sus palabras exteriorizan 
envidia y odio hacia la chica, pues a su corta edad sabe de los dolorosos placeres del matrimonio y la sexualidad, de ahí que Cecilia recuerde al victimario. El paralelismo entre la historia de Cecilia y Sohad culmina cuando "No quedaba más que pasar la página aunque la hemorragia se extendiera como el café derramado en el mantel" (32); es decir, cuando aflora el símbolo violento de la sangre expandiéndose en ambas historias, pues "Tan pronto como se desencadena la violencia, la sangre se hace visible, comienza a correr y ya es imposible detenerla, se introduce por todas partes, se esparce y se exhibe de manera desordenada" (Girard, 1998: 4041).

En resumen, las vidas de Blanca y Sohad le permiten a Cecilia proyectarse, sabiendo que "Mediante la proyección atribuimos al mundo externo, lo que percibimos y experimentamos en nuestro interior" (Amara, 1998: 118). De esta forma, la insípida vida de Cecilia se ancla en las terribles experiencias de Blanca y Sohad, pero además atribuye a ellas muchas deficiencias de su carácter: Blanca es una "neurótica más" y Sohad una "escuincla".

El final del cuento, en una clara evasión de los problemas medulares, presenta a una Cecilia supuestamente despreocupada: "Puede tomarse un ansiolítico, oír música, olvidar a Tere y al periódico, a Sohad y a la oficina, a mamá. De todos modos esas historias no tienen que ver una con otra ni hay remedio ni vale la pena angustiarse, perder más tiempo pensando en esas cosas" (1995: 32); aparentemente Cecilia suprime todas esas catástrofes remotas que, en el fondo, la enfrentan con su existencia solitaria, vacua y mediocre, en tanto no se atreve a vivir libremente y en pos de su dicha.

En "Cacería nocturna", la protagonista ubica a un hombre en una ordinaria reunión social y con él la oportunidad de escapar al hastío y monotonía que la invade a través de una relación erótica imaginada por la narradora como animales en busca de su presa: 
En esa luz nos reconocimos con gruñidos roncos que apenas son un ruido y parecían llegar desde otro tiempo. Pese a todo el polvo pude ver a través de tus ojos que alguna vez ese farol había sido una luna; habíamos dormido sobre las malezas con el olor del bosque curvado sobre nosotros, exhaustos de correr toda la noche tras los antílopes y por fin lamer su sangre salpicada, tú sobre mi cara y yo en tantos lugares de la tuya, lamer la sangre sobre tu pecho, el sabor de la carne cruda. Había sido el olor aterrado del herbívoro al sentirnos cerca y saber que estaba perdiendo la carrera, no llegaría a la charca, eran sus últimos pasos, su última voz cuando le saltaste al cuello y rodaron entre el polvo y el pavor de la manada en estampida. Los despedazamos juntos, hundimos los hocicos en sus músculos desgarrados, en el vaho caliente, ese olor que nos obligaba a buscar más y más adentro del cuerpo inerte, borrachos con los sonidos ásperos que nos salían de la garganta, tu rugido tan cerca de mí, casi encima de mi cara, exultante pese a la sábana llena de arrugas y moronas (56)

Esta relación erótica, fantaseada como un destrozar a la presa, como un acto violento, es trascendente para la mujer, pues gracias a ella modifica su apagada existencia al descubrir una situación nueva, mediante el vínculo establecido con aquel hombre, compañero en y después del suceso imaginario:

[...] cuando bajaste la cabeza y pediste un café y recuperaste tus ademanes torpes supe que podía apartarme de la arruga en la sábana, correr por las escaleras, pasarme al otro lado de la puerta $y$ salir a la calle ya sin ninguna traza de cacería, convertida completamente en mí como ahora mismo que es tarde y que tengo que levantarme. Aparto las sábanas hechas de sombras y malezas y las dejo caer sobre esta cueva debajo de mi almohada donde está presa tu alma y sólo yo puedo desatarla, tu alma con todas y cada una de sus garras (57-58). 
El erotismo y la violencia originan una relación amorosa basada en el deseo de posesión advertido en la protagonista, quien se siente satisfecha al apresar el alma del hombre.

"Lejos" es otro breve y sugerente texto. Mediante un narrador intradiegético en segunda persona, conocemos la historia de la protagonista, quien ha abandonado su espacio familiar e iniciado un viaje por tierras ignotas. Esta decisión le permite reconocerse como una mujer independiente, huyendo de los límites impuestos: "Mientras cabalga imagina la montaña. Tiene primas que llevan vidas apacibles y cada día se ponen un traje distinto para derrotar el gris de la ciudad. Son señoras de haciendas, obrajes, alhóndigas repletas, cortijos" (60). En oposición a estas mujeres, la protagonista se ha aventurado por inexploradas montañas, cabalgando cual libre jinete; sin embargo, irrumpe un sentido metafórico sobre tal hecho: "Y ahora, al picar espuelas, entiende: para usted los hombres son montañas" (60), un sutil erotismo aflora vinculado con esta metáfora: "Son señales: la montańa empieza a abrirse. Cuando despierte descubrirá maneras de subir entre piedras desgajadas hace miles de años" (61). Evasión de la cotidianidad y delicado erotismo definen a este relato.

"Cuento Kitsch" es el único texto fantástico de Cuentos para ciclistas y jinetes, pero igualmente emerge el trinomio evasión, erotismo y violencia. Armanda, la atractiva protagonista, despierta con el antojo de "carne joven”. Al consultar las cartas, éstas le auguran un hombre magnífico. Ante ello, emprende una búsqueda donde lo encuentra y, sumergida en la imperiosa seducción, lo invita a su casa a concretar una relación erótica. El final deviene sorpresivo, pues revela a una mujer convertida en lagarto, rodeada por los restos del otrora amante y hoy insignificante pedazo de hueso y piel.

La insólita historia de Armanda comienza en su pasado: "Pensar que alguna vez fui ama de casa sincronizada al reloj de la cocina" (11-12). Armanda huye de su rol, en tanto se halla abrumada por 
el hábito y sus inherentes quehaceres domésticos. Posteriormente, adquiere una nueva personalidad donde es una lagartona; este término supone tanto a "la mujer que va dejando atrás su juventud y lozanía, pero con una gran experiencia amorosa" (Domenella, 1999: 361), como literalmente al animal; esta anfibología le permite al narrador regodearse en la ambigüedad discursiva: "Con un latigazo de culebra se arrojó fuera de la casa decidida a devorar kilómetros, países enteros si era necesario. A su paso quedaban regueros de árboles tronchados, surcos donde jamás volvería a crecer la hierba, estelas de lágrimas y hogares destrozados: la marca de la depredadora" (González Mateos, 1995: 13). Armanda, lejos de su anterior vida, se transforma en una lagartona.

La metamorfosis es uno de los temas más notables del subgénero fantástico. Para Tzvetan Todorov, forman parte de los temas del Tú, en tanto "constituyen una transgresión de la separación entre materia y espíritu" (1994: 91) y, por lo tanto, indica una trasgresión de las leyes del mundo cotidiano, instaurando un nuevo orden donde prevalece la ambigüedad, esa débil balanza donde se fusionan dos seres de naturaleza distinta, como sucede en "Cuento Kitsch" con la protagonista al ser una mujer-animal. Una representación de esta ambigüedad aflora cuando Armanda conoce al hombre en el bar y -a pesar de su actitud pasiva, como objeto de deseo en espera de la conquista del otro- le comenta no ser lo que parece, pues no es el objeto, sino el sujeto activo, la devoradora.

La metamorfosis de Armanda conlleva una alta dosis de violencia enlazada con el erotismo, la cual se confirma en tres momentos relevantes: en primer lugar, cuando Armanda despierta con un "antojo" de "carne joven"; en segundo lugar, cuando descubre en un naipe una imagen paradigmática e inverosímil, posiblemente un as de bastos o de espadas, ambos símbolos fálicos (Becker, 1999: 127) y vaticinio de un gran amante; finalmente, cuando el narrador comenta: 
Al despertar Armanda al día siguiente los husecillos mondos hacían incómoda la almohada. Sorbió un poco de tuétano adherido a un trozo largo (¿habría sido una pierna? Hizo un esfuerzo por reconstruir el movimiento de los muslos, la textura de la piel velluda, pero sólo quedaban unos pellejos chupados, buenos para el congelador, si acaso) (15).

Esta sanguinaria, bestial e impulsiva acción de Armanda resulta un acto de suma violencia, pues ha cometido antropofagia. Así, la protagonista de "Cuento Kitsch" ha esquivado su cotidianidad (ser una ama de casa) a través de la transgresión y la ambigüedad implícitas en lo fantástico, lo cual la conduce al erotismo y su tácita violencia.

"Cuento Kitsch" y "Cacería nocturna" comparten algunas semejanzas. En los dos cuentos existe un matiz necrofílico, una cierta "pasión por destrozar las estructuras vivas" (Amara, 1998: 115), ratificada cuando las protagonistas destruyen a su presa, deleitándose durante y después del hecho. Según Giuseppe Amara, la víctima del necrofílico debe ser una presa desconocida, sin pasado ni nombre, y fácil de dominar, pues sólo así lo retendrá en su fantasía (121). En "Cuento Kitsch", Armanda emprende la búsqueda del hombre, de quien ignora todo, salvo se suponía era el idóneo para sus intereses de rehuir lo cotidiano por lo erótico, resultando una presa asequible al no objetar nada cuando Armanda le advierte no ser lo que parece; también en "Cacería nocturna" la protagonista desconoce al hombre, pues de él sólo sabe que era el indicado para sortear su situación opresiva.

Otra similitud se halla en la presencia de la sangre como símbolo violento. En "Cacería nocturna" surge cuando la protagonista se imagina la relación sexual como animales en exterminio de su presa, saboreando la sangre y la carne cruda sobre el cuerpo del otro; en "Cuento Kitsch" aparece implícita, no sólo imaginada, hacia el 
final, cuando Armanda despierta rodeada de los huesos, tuétano y pellejos del anónimo hombre, a quien se ha engullido.

Finalmente, El lenguaje de las orquideas presenta dos personajes femeninos maduros con similar esquema al estudiado: la abuela y la narradora. Respecto a la abuela: "Desafió los prejuicios y se enfrentó a las consecuencias. Se escapó con él dejando en una silla el vestido de novia" (González Mateos, 2007: 53); esta evasión del dominio masculino deviene fugaz, pues entabla otra relación amorosa que la conduce directamente a la maternidad y "los nińos le abrumaban" (57); por ello, con el paso del tiempo, se convierte en una mujer hiriente y acerba. Sin embargo, su papel es definitivo para la protagonista con quien entabla cierta connivencia: "Quizá fue insoportable, abusiva, hasta despiadada. Pero a nadie trató tan mal como a ella misma, ni tan bien como a mí [...] mi abuela cálida y divertida, cómplice" (61).

Como si fueran imágenes especulares, la abuela y la narradora se instauran como personajes en búsqueda de su libertad. De este modo, la abuela, pese a sus desaciertos y fracaso, termina encumbrada gracias a la remembranza de la narradora: "La fascinación de su recuerdo está ligada a esa atmósfera aromática y cambiante que le daba un aire de sacerdotisa" (52). Por su parte, la nieta ha recuperado su añeja historia de transgresión con el tío, ha confesado los detalles de la historia, se ha purificado de su desafío eróticoviolento al cometer incesto y ahora impasible confiesa: "Respiré como si no lo hubiera hecho en mucho tiempo; de pronto el aire me pareció muy fresco, casi sabroso. Descubrí la sensación de esa corriente circulando en mi cuerpo, llegando a lugares hasta entonces cancelados por el silencio" (109).

Abuela y nieta, en la evasión de su contexto, en la transgresión (por el erotismo y la violencia) y en el contar su historia, se representan con la imagen final de la novela que además le da título: el lenguaje de las orquídeas. Si bien surge el motivo de la orquídea de 
brotes rotos, lastimada y cercenada, finalmente, como lo afirma la narradora "Una orquídea no es exactamente una planta: es un ser que domina el lugar donde se encuentra” (111) y ambas mujeres lo ejemplifican.

\section{Conclusiones}

Tanto en Cuentos para ciclistas y jinetes como en El lenguaje de las orquideas la evasión de lo cotidiano es un eje temático fundamental, así como sus principales mecanismos de efugio: el erotismo y la violencia. Específicamente, "Gatúvela", "Sueño con enredadera", "Solitarios", “Toros” y El lenguaje de las orquideas exhiben protagonistas púberes agobiadas por la vida cotidiana (cambios físicos, vida escolar y familiar), de la cual se sustraen por una iniciación erótica, donde la transgresión, la fantasía, el sueño y la violencia cumplen una función primordial; por supuesto, algunas iniciaciones resultan luminosas, por lo placenteras ("Gatúvela", "Solitarios"), o fracasadas, por el predominio del desconcierto y la crueldad ("Sueño con enredadera", "Toros", El lenguaje de las orquideas). Por su parte, "Catástrofes remotas", "Cacería nocturna”, "Lejos", "Cuento Kitsch" e igualmente El lenguaje de las orquídeas presentan mujeres adultas con problemáticas cotidianas familiares y amorosas, de las cuales se evaden mediante el erotismo y la violencia. Resultados negativos se observan en "Catástrofes remotas" y en la abuela de El lenguaje de las orquideas, pues finalmente no logran escapar de su áspera rutina; no obstante, en "Cacería nocturna”, "Lejos", "Cuento Kitsch" y en la protagonista de la novela (ya como mujer), se perciben procesos benéficos, pues en todos estos los personajes han logrado eludir la inercia y vivir el erotismo con su implícita violencia, resultando transgresoras, libres y plenas.

Las temáticas estudiadas se complementan con recursos simbólicos como la sangre, las tijeras y los animales como la víbora, 
el toro o el zopilote. En este sentido, los cuentos confieren dos símbolos relevantes para la narrativa de Adriana González Mateos: los "Ciclistas", personajes en constante movimiento, apartados de lo inerte, símbolos de la fuga del mundo apremiante y rutinario a través de la bicicleta, y los "Jinetes", quienes igual apelan al movimiento por medio del caballo, simbolizando la juventud, la virilidad y la sexualidad (Becker, 1999: 58), pero también el escape y el dinamismo.

En la narrativa de Adriana González Mateos sus personajes femeninos esquivan o, al menos, pretenden eludir el cotidiano letargo, otro inadvertido rostro de la muerte, en tanto varias de estos emprenden la búsqueda de su libertad y realización sin ningún tipo de atadura, mediante el erotismo y la violencia, esperando encontrar al otro lado del sendero, allá donde los ciclistas y los jinetes prescinden de la bicicleta y del caballo, un lugar más afortunado, donde el placer erótico y la violencia los aleje de la fúnebre e irrelevante bruma cotidiana y donde se les permita vivir en plenitud, cual indómitas orquídeas.

\section{Bibliografía}

Amara, Giuseppe, 1998, Cómo acercarse a la violencia, Conaculta, México.

Bataille, George, 2008, El erotismo, Tusquets Editores, México.

Bataille, Georges, 2007, Las lágrimas de Eros, Tusquets, Barcelona.

Becker, Udo, 1999, Enciclopedia de los símbolos, Océano/RobinBook, Barcelona.

Cirlot, Juan Eduardo, 2008, Diccionario de símbolos, Siruela, Madrid.

Domenella, Ana Rosa, 1999, “Tres cuentistas "neofantásticas”, en Cuento y figura (La ficción en México), Alfredo Pavón (ed., pról. 
y notas), Universidad Autónoma de Tlaxcala, México, pp. 351375.

Domínguez Michael, Christopher, 2007, "Un estudio de mujer", El Ángel, núm. 682, 15 de julio.

García Aguilar, Eduardo, 1996, "El texto como huella digital”, $\mathrm{La}$ Jornada Semanal, núm. 47, 28 de enero, p. 15.

García, Mara L., 1999, "El proceso creativo en Rosario Castellanos", en Cuento y figura (La ficción en México), Alfredo Pavón (ed., pról. y notas), Universidad Autónoma de Tlaxcala, México, pp. 99-106.

Genovés, Santiago, 1993, Expedición a la violencia, FCE, Universidad Nacional Autónoma de México, Colección popular 453, México, pp. 153-154.

Girard, René, 1998, La violencia y lo sagrado, Anagrama, Barcelona.

González Mateos, Adriana, 1995, Cuentos para ciclistas y jinetes, Aldus/Difocur-Sinaloa, México. ,2007, El lenguaje de las orquideas, Tusquets, México.

Lugo, José Antonio, 1995, "Escribir es una forma de galopar”, El Nacional, núm. 67, México, 17 diciembre, p. 35.

Martínez Fernández, José Enrique, 2001, La intertextualidad literaria, Cátedra, Madrid.

Todorov, Tzvetan, 1994, Introducción a la literatura fantástica, Ediciones Coyoacán, México. 